\title{
VISION, LIGHT AND COLOR IN AL-KINDĪ, PTOLEMY AND THE ANCIENT COMMENTATORS
}

\author{
PETER ADAMSON
}

One of the products of the Arabic reception of Greek science that began under the "Abbāsid caliphate in Baghdad in the 3rd century A.H. (9th c. A.D.) was a considerable advance in the field of optics. ${ }^{1}$ Ibn al-Haytham (d. 432 A.H. / A.D 1040) ranks as the most famous writer on optics in Arabic science, and deservedly so, for he was the first to grasp that vision occurs because rays of light go from the perceived object to the eye. ${ }^{2}$ Among the important precursors of Ibn al-Haytham was the philosopher al-Kindī (d. ca. 256 / 870), who presided over important translations of scientific and philosophical works from Greek into Arabic. ${ }^{3}$ Al-Kindī's works are notable for the wide range of interests they display. In addition to works

${ }^{1}$ On the transmission of Greek philosophy and science to the Arabic speaking world generally, see C. D'Ancona, La Casa della Sapienza (Naples, 1996); A. Badawī, La transmission de la philosophie grecque au monde arabe (Paris, 1968); G. Endress, "Die wissenschaftliche Literatur," in Grundri $\beta$ der arabischen Philologie Bd. III, Supplement, edited by W. Fischer (Wiesbaden, 1992); D. Gutas, Greek Thought, Arabic Culture (London, 1998); F. E. Peters, Aristoteles Arabus (Leiden, 1968).

${ }^{2}$ On Ibn al-Haytham see D. C. Lindberg, Theories of Vision from al-Kind $\bar{\imath}$ to Kepler (Chicago, 1976); S. B. Omar, Ibn al-Haytham's Optics (Minneapolis, 1977); A. I. Sabra, The Optics of Ibn al-Haytham Books I-III: On Direct Vision, vols. 1-2 (London, 1989); A. M. Smith, "Extremal principles in ancient and medieval optics," Physis, 31 (1994): 113-40. For an overview of Arabic optics up to the time of al-Haytham, see E. Kheirandish, "The many aspects of 'appearances': Arabic optics to $950 \mathrm{AD}$," in J. P. Hogendijk and A. I. Sabra (eds.), The Enterprise of Science in Islam (Cambridge, MA, 2003), pp. 55-83.

${ }^{3}$ For overviews of al-Kindī against the background of the translation movement, see G. Endress, "The circle of al-Kindī," in G. Endress and R. Kruk (eds.), The Ancient Tradition in Christian and Islamic Hellenism (Leiden, 1997), pp. 43-76; P. Adamson, "Al-Kindī and the reception of Greek philosophy," in The Cambridge Companion to Arabic Philosophy (Cambridge, 2005), pp. 32-51. I will shortly publish a monograph devoted to al-Kindī's thought in the Oxford University Press series Great Medieval Thinkers. Peter Pormann and I are at work on a book of translations, entitled The Philosophical Works of al-Kind $\bar{\imath}$, also to appear with Oxford University Press. This will include translations of the works on color discussed in the present article. 
on metaphysics, psychology, ethics, and so on, which have attracted the most attention from modern scholars, he wrote treatises (usually in the form of epistles) in an astonishing variety of scientific disciplines. ${ }^{4}$ Among his several studies of optics is a work that builds on Euclid's Optics, and is preserved only in Latin under the title De Aspectibus. ${ }^{5}$ This will serve as the subject of the first part of the present paper.

While De Aspectibus was al-Kindī's most influential work on optics, because it was read widely by the medievals in Latin translation, it was not his only foray into the theory of vision. In addition to the other optical works studied recently by Rashed, we possess two epistles on color that are extant in Arabic, one On the Bearer of Color and one On the Cause of the Blue Color of the Sky. ${ }^{6}$ These two short texts are not, as De Aspectibus is, in the genre of geometrical optics, but they are helpful in establishing al-Kindī's understanding of vision and light. In particular, as I will show in the second part of the paper, they shed further light on al-Kindī's attitude towards the visual theory that came down to him from Aristotle and his commentators.

There has been, as yet, no attempt to understand the relation between these works on color and al-Kindī's writings on optics. Looking at how al-Kindī deals with problems of light and color in two very different contexts - Euclidean geometrical optics, on the one hand, and Aristotelian visual theory, on the other will allow us to test the limits of his effort at reconciling Greek sources. To what extent did he try to achieve consistency in these different kinds of works? In the present case, we have a

\footnotetext{
${ }^{4}$ The most useful list of works by al-Kindī is in P. Travaglia's recent book Magic, Causality, and Intentionality. The Doctrine of Rays in al-Kind $\bar{\imath}$ (Turnhout, 1999), which has an appendix listing all of his extant works with manuscripts, editions, translations and secondary literature.

${ }^{5}$ De Aspectibus is a Latin translation by Gerard of Cremona, probably of the no longer extant Kitāb fī 'Ilal ikhtilāf al-manāzir mentioned in Ibn al-Nadīm's Fihrist: see R. Rashed, Euvres philosophiques et scientifiques d'al-Kind, vol. 1: L'optique et la catoptrique (Leiden, 1997), p. 67. I will quote from the Latin text in Rashed's edition. All translations of this and other works are my own unless otherwise noted.

${ }^{6}$ Or, in their full titles, On the Body that is By Nature the Bearer for the Color of the Four Elements, and which is the Cause of the Color in Things Other than Itself, and On the Cause of the Blue Color that is Seen in the Air in the Direction of the Sky, and is Thought to be the Color of the Sky. Both can be found in the second volume of Al-Kindī, Rasā'il al-Kind̄̄ al-falsafiyya, edited by M. Abū Rīda, 2 vols. (Cairo, 1950, 1953). I will henceforth refer to volume 1 of this work as AR, and volume 2 as $\mathrm{AR}^{2}$.
} 
specific version of this question: to what extent did works on geometrical optics inform his reading of the Aristotelian theory of light and color, and vice-versa? I will argue for the conclusion that we find influence in both directions. That is, he borrows from the Peripatetic tradition when writing De Aspectibus, and adapts the Aristotelian theory of vision to fit the optical theory he has from the geometrical tradition. Al-Kindī's attempt to marshal together a range of different, and sometimes mutually contradictory, sources thus resulted in a new understanding of vision, light and color.

Before I begin, a caveat: I am not an expert in the history of optics, mathematics, or the use of geometry in the physical sciences. My interest here is only in al-Kindī's philosophical views on the subject of vision. Thus my attention will be devoted solely to discussing the theoretical underpinnings of his optical works, and to juxtaposing these with the views put forward in his works on color. Since this is the goal of the present paper, I will not be engaging in a detailed study of the aims or plan of De Aspectibus as a whole, nor will I have much to say about the specific geometrical demonstrations found in it. Fortunately these are tasks that have been undertaken elsewhere by more able historians of science. Still, I hope that the following may contribute something to the work of scholars of the optical tradition, given that there is no firm dividing line to be drawn between philosophical and scientific discourse in the case of an author like al-Kindī.

\section{DE ASPECTIBUS}

Al-Kindī's De Aspectibus, like its chief source, the Optics of Euclid, consists of a series of geometrical demonstrations based on a set of axioms. ${ }^{7}$ Al-Kindi is in essential agreement with Euclid about how vision works: he adheres to the "extramission" theory, according to which we see because rays are emitted from our eyes. When these rays fall upon a visible object, we see that object. There are two chief advantages of this theory. First, because the rays can be formalized as

\footnotetext{
${ }^{7}$ On the transmission of the Optika see E. Kheirandish, The Arabic Version of Euclid's Optics, 2 vols. (New York, 1999); and also her "The Arabic 'version' of Euclidean optics: Transformations as linguistic problems in transmission," in F. J. Ragep and S. P. Ragep (eds.), Tradition, Transmission, Transformation (Leiden, 1996), pp. 227-43.
} 
straight lines, it allows for the application of geometry to optics, so that one can give mathematical demonstrations for various laws of perspective. Second, it explains sight by assimilating vision to touch, an assimilation which in one way or another underlies all ancient theories of vision. ${ }^{8}$ We may add that the extramission view allows al-Kindi to avoid objections against the alternative, "intromission" view, according to which we see because images (eidôla) are emitted from visible objects and enter our eyes. There were several such objections. For example, why do the images not collide with one another? How do the images become small enough to fit through the pupil? Critics like Alexander of Aphrodisias used these and similar points to argue against the intromission theory of the ancient atomists. ${ }^{9}$

Al-Kindī, much more than Euclid, attempts to give a comprehensive account of the mechanism of vision. He argues explicitly (Prop. 1-6) for the claim that visual rays and light rays travel along straight lines, drawing on the arguments ascribed to Theon of Alexandria in a recension of Euclid's Optics. ${ }^{10} \mathrm{He}$ refutes three rival theories of vision (Prop. 7): an intromission view like that of the atomists, a view that combines both introand extramission, and the view according to which "the forms [of the visible objects] are inscribed and impressed in the air, and the air inscribes and impresses [the forms] on the eye, and the eye grasps them through its power for receiving what the air impresses in it, through an illuminated medium (lumine mediante)." The second theory seems to be that of Plato's Timaeus, according to which a ray emitted from the eye fuses with light outside the eye, and sight results from this fusion

${ }^{8}$ As D. C. Lindberg has noted, in the ancient world "the analogy of perception by contact in the sense of touch seemed to establish to nearly everybody's satisfaction that contact was tantamount to sensation, and it was not apparent that further explanation was required" (Lindberg, Theories of Vision, p. 39).

${ }^{9}$ See I. Avotins, "Alexander of Aphrodisias on vision in the atomists," Classical Quarterly, 30 (1980): 429-54. For Alexander's In de Sensu, see further below.

${ }_{10}$ See Rashed, Euvres philosophiques, pp. 45-52, providing parallels between Theon and al-Kindī. An earlier study of De Aspectibus by D. C. Lindberg, "Alkindi's critique of Euclid's theory of vision," Isis, 62 (1971): 469-89, also notes the dependence of al-Kindī on Theon: see p. 474, n. 23. The "Theon" recension is edited in I. L. Heiberg, Euclidis Opera Omnia (Leipzig, 1945), vol. VII: Euclidis optica, opticorum recensio Theonis, catoptrica, cum scholiis antiquis, pp. $144 \mathrm{ff}$. 
(see Timaeus, 67d-68d). ${ }^{11}$ The third and final theory is, of course, Aristotle's view in the De Anima. Al-Kindī refutes it using a clever example based on Theon: if we see a circle from the side, we see a line, not a circle. But according to Aristotle's theory, a circle should transmit its own (circular) form through the medium. Aristotle does not, in short, give us the resources to explain why things look different from different angles.

In subsequent propositions al-Kindī expands his account of how vision works. The visual rays that come from the eye form a cone, whose base is at the pupil. This allows him to explain why peripheral vision is weaker than vision of something directly in front of us. At first, he claims that this is due to the fact that perpendicular lines strike their object more strongly than oblique lines. ${ }^{12}$ But then he gives a more sophisticated explanation: an object in the middle of our visual field will be struck by a greater number of visual rays, because a straight line can be drawn to the object from any point on the pupil's surface. ${ }^{13}$ An object in our peripheral vision is, by contrast, seen by rays from only some of the points on that surface (Prop. 12). ${ }^{14}$ But that explanation, and al-Kindī's demonstration of the explanation, depend on the claim that every point on the surface of the pupil emits rays in all possible directions. When applied to light rays as well as visual rays, this claim constitutes al-Kindī's most significant advance in De Aspectibus:

${ }^{11}$ Han Baltussen has brought to my attention that this taxonomy of visual theories has echoes as far back as Theophrastus, who calls Plato's theory a “middle" view. See H. Diels, Doxographi Graeci (Berlin, 1879), p. 500.

${ }^{12}$ De Aspectibus, Prop. 12, 11. 64-5: "I say then that a stronger [visual] ray falls on what is in the center of vision. As a result it is seen more clearly (Dico ergo quod super centrum visus cadit radius fortior. Quaepropter quod in eo est manifestus videtur)." The claim that rays along perpendicular lines have a stronger effect also appears in al-Kindī's De Radiis, ch. 2, 219.16-18: "For a ray that falls from the center of a star to the center of the earth falls is found to produce the action of its species most strongly, whereas those that fall on the center of the earth obliquely are weakened in their effects in proportion to their obliqueness (Nam radius qui a centre stelle ad centrum terre descendit fortissimus esse probatur in operationis sue specie. Qui autem a centro terre obliquantur secundum proportionem obliquationis in effectu debilitantur)."

${ }_{13}$ An anonymous referee for this journal has suggested to me that the apparent tension could be resolved by noting the ambiguity of the term "ray": understood as the physical visual ray, a perpendicular ray is stronger than an oblique one. The more sophisticated solution in fact undergirds this claim by showing that such a ray can be formalized as mathematical rays, and the perpendicular (physical) ray will have a greater number of (mathematical) rays falling on a given visual object.

${ }^{14}$ On these two accounts see Lindberg, “Alkindi's critique,” pp. 481-3. 
every point on the surface of a luminous body emits light rays in all possible directions (Prop. 13-14). This has been called the "punctiform analysis" of light, and anticipates the theory of Ibn al-Haytham. ${ }^{15}$ Al-Kindī also argues that light (Prop. 15) is propagated instantly along a straight path; it does not affect the air one part after another.

These, then, are the main theoretical points made in $D e$ Aspectibus on the nature of vision and light. Perhaps the most surprising feature of our summary, especially in the context of al-Kindī's other works, is the lack of sympathy shown for the Aristotelian account of light. Certainly the De Anima analysis of vision failed to explain numerous visual phenomena, such as the circle seen from an oblique angle. Yet al-Kindī's contemporary, the translator and scientist Hunayn ibn Ishāa (d. 259 / 873), lists exactly the same four theories of optics as al-Kindī in one of his Galenic treatises on the eye, and himself opts for the Aristotelian view. ${ }^{16}$ In other works al-Kindī seems, like Hunayn, to accept without question Aristotle's theory of vision from De Anima. For example, in On the Definitions and Descriptions of Things, he defines "imagination (tawahhum)," "sense (hāss)," "sensation (hiss)," and "the sensible (almahsūs)" all in terms of the forms (șwar) present in the things that are apprehended. ${ }^{17}$ Of course these definitions are culled from various sources and may not represent al-Kindī's own views. But in the original epistle On the Quiddity of Sleep and Dream, he says that "the sensibles are in the soul not different from sensation" and "the faculty that perceives the sensibles, and which is common to all animals, [is what perceives] the forms of individual things, I mean individual forms such as the forms of color, shape (al-ṣuwar al-shakhșiyya allatī hiya allawniyya, al-shakliyya)" and so on. ${ }^{18}$ Such passages certainly imply that we see because the faculty of sight perceives by

15 See Lindberg, "Alkindi's critique."

16 M. Meyerhof, The Book of Ten Treatises on the Eye Ascribed to Hunain Ibn $I s-H \bar{a} q$ (Cairo, 1928), in the third treatise ("On the Subject of Vision"), pp. 20-39. Hunayn's source here is Galen's On the Doctrines of Hippocrates and Plato, in Phillip de Lacy (ed.), Corpus Medicorum V 4 1,2 (Berlin, 1980). See pp. 452-4 for Galen's discussion of the extramission and intromission views.

${ }^{17}$ AR 167.9-17. For the question of the authenticity of On Definitions see P. Adamson, "Al-Kindī and the Mu'tazila: Divine attributes, creation and freedom," Arabic Sciences and Philosophy, 13 (2003): 45-77, at pp. 75-6, n. 87.

${ }^{18}$ AR 301.12, 302.5-7. 
taking on the form of what is seen, just as Aristotle says in $D e$ Anima.

On the other hand, al-Kindī's other works are not as inconsistent with De Aspectibus as it may appear. Although he accepts that we perceive visible forms, he is always neutral about the mechanism by which we perceive them. ${ }^{19}$ Nowhere does al-Kindī imply that we must perceive forms through some sort of intromission view. In any case, al-Kindī may, like modern scholars, have been troubled by Aristotle's own inconsistency on the question of the mechanism of vision. In the Meteorology and De Caelo he adopts an extramission theory like that of Plato, Euclid and al-Kindī. ${ }^{20}$ Still, it is clear that De Aspectibus considers and rejects an identifiably Aristotelian theory of vision.

Al-Kindî's fidelity to Euclid is also less than complete. De Aspectibus diverges from the Optics on a number of points. This is done more in a spirit of charity than criticism: al-Kindī says in De Aspectibus, Prop. 11, 1l. 79-81, that we should not be eager to attribute an error to a figure like Euclid, but instead "we should think well of him and shift what he says to the right path (convertamus eius sermonem ad semitam bonam)." In the rest of this section I want to consider three such shifts:

(A) Euclid presents visual rays as one-dimensional lines emitted to form a cone. Al-Kindi argues that the rays must in fact be three-dimensional.

(B) Euclid also believed that as the lines emitted from the eye spread out, there will be gaps between them; this is why we do not see things clearly when they are far away. Al-Kindi denies this, and holds that the visual cone is continuous.

(C) Finally there is the aforementioned account of how light is propagated: along straight lines, but having an instantaneous effect over the whole extent of its path (in other words, light does not travel).

19 Consider, for example, this passage from On First Philosophy: "our perception through the senses, upon direct contact (mubāshara) of sense with its object, is not in time" (AR 106.8). Here al-Kindı̄'s statement is consistent with Aristotle, but emphasizes only the fact that sensation is through contact, which as previously mentioned is common to all ancient theories of vision. By the same token, al-Kindī does not try to bring together the Aristotelian doctrine of visible forms with his extramissionist mechanics.

${ }^{20}$ See A. Jones, "Peripatetic and Euclidean theories of the visual ray," Physis, 31 (1994): 47-76. As we will see below there is evidence that al-Kindi knew the Meteorology. 
What inspired al-Kindī to depart so significantly from his source text? An obvious explanation is that Euclid's Optics was not the only work on which he drew. Here I will discuss two further sources. Firstly, and as others have noted, al-Kindī was influenced by ideas that originated in the Optics of Ptolemy. ${ }^{21}$ In the next section, I will explore how these Ptolemaic ideas were put to use by al-Kindī in forming his philosophical theory of vision. In part II of the article I will further suggest that Ptolemaic ideas also had an impact on al-Kindī's works on color. The second source is John Philoponus' Commentary on the De Anima, ${ }^{22}$ mediated by an Arabic paraphrase of Aristotle's De Anima that includes material from Philoponus. I will take the two sources in turn.

\section{I.1. Ptolemy's Optics}

Unfortunately, though we know that there was an Arabic version of Ptolemy's Optics (indeed the only extant version is a Latin translation of the Arabic version), we do not know when it was produced. It was used by Ibn al-Haytham, and also by an earlier author, Ibn Sahl, writing in the late 10th century. ${ }^{23}$ Al-Kindî's apparent use of Ptolemaic ideas is the only evidence that the Optics might have been available in the mid-9th century. Scholars' answers to the question of whether al-Kindi knew it in an Arabic version have ranged from an emphatic "yes" 24 to an emphatic "no" 25 by way of a less emphatic

${ }^{21}$ I would like to thank Stephen Menn for encouraging me to pay more attention to Ptolemy as a source for al-Kindī's ideas. Latin edition and French translation in A. Lejeune, L'optique de Claude Ptolémée (Leiden, 1989), which reprints the Latin from A. Lejeune, L'optique de Claude Ptolémée (Louvain, 1956). English translation in A. M. Smith, Ptolemy's Theory of Visual Perception: an English Translation of the Optics with Introduction and Commentary (Philadelphia, 1996). I will quote the Optics using Smith's translation.

22 Joannes Philoponus, In Aristotelis De Anima libros, edited by M. Hayduck, $C A G \mathrm{XV}$ (Berlin, 1897). The section on vision in the commentary has been translated as an appendix to J. de Groot, Aristotle and Philoponus on Light (New York, 1991). A German translation of the relevant sections can be found in Walter Böhm, Johannes Philoponus: ausgewählte Schriften (Munich, 1967), pp. 174-207.

${ }^{23}$ For the reception of Ptolemy's Optics in Arabic see Sabra, The Optics of Ibn al-Haytham, vol. 2, pp. lviii ff.

24 A. A. Björnbo and S. Vogl, "Alkindi, Tideus und Pseudo-Euclid. Drei optische Werke," Abhandlungen zur Geschichte der mathematischen Wissenschaften, 26.3 (1912). This view is followed by Lejeune in his edition of the Optics, at Lejeune, L’optique de Claude Ptolémée (1989), p. 29*. 
"perhaps." 26 However there is general agreement that there was at least indirect influence, and nothing in my argument turns on the question of whether al-Kindī had direct access to an Arabic Optics. ${ }^{27}$

What, then, are the Ptolemaic ideas operative in $D e$ Aspectibus? First, the notion that perpendicular rays are stronger than oblique ones is found in Ptolemy. ${ }^{28}$ As we saw al-Kindī at first embraces this explanation of why perpendicular vision is weaker, but then supplants it with an improved account. Further evidence is provided by points (A) and (B) listed above. Taking these together, we have the view that (A) the visual cone is made up of rays that are not geometric abstractions, but actual three-dimensional, physical entities; and, further, that (B) the rays are continuous with one another. The visual cone is thus like a body in Aristotle's continuist physics (which al-Kindī broadly accepts, having been a critic of atomism $\left.{ }^{29}\right)$ : indefinitely divisible. Thus, as al-Kindī points out, and as will be important shortly, the rays are not literally lines, and do not contact the visual object at points, but rather the ray strikes an extended area on the surface of what is seen. ${ }^{30}$

${ }^{25}$ Rashed, Euvres philosophiques, p. 46: "al-Kindī attribue en particulier à Théon une conception du cône visuel inspirée de celle de Ptolémée, et non pas de celle d'Euclide; il ne nous livre cependant pas sa source, et la seule certitude que nous ayons à cet égard est qu'il n'a pas eu accès à l'Optique de Ptolémée."

${ }^{26}$ Sabra, The Optics of Ibn al-Haytham, vol. 2, p. viii: citing Vogl, he remarks that it is "strongly suggested" by some parallels.

${ }^{27}$ One reason to reject a direct reading of the Optics is that al-Kindi fails to make use of Ptolemy's ideas on refraction. The fact that in the Rectification of Euclid (§3, 173.23-25) al-Kindī mentions Ptolemy alongside Theon of Alexandria supports the view that al-Kindī's acquaintance with Ptolemaic ideas was through the intermediary of Theon. I am grateful to two anonymous referees from this journal for their remarks on this issue.

${ }^{28}$ Ptolemy, Optics §19, 19.18-20.1: "For everything that falls orthogonally strikes its subjects more intensely than whatever falls obliquely (Omnia enim quorum casus fit secundum perpendiculares lineas, habent inclubitum super subiecta magis quam ea quorum casus fit obliquus)."

${ }^{29}$ The Fihrist ascribes to al-Kindī an epistle F̄ Buṭlān qawl man za'ama anna juz' la yatajazz $\bar{a}^{\prime}$ (On the falsity of the statement of one who alleges that there is an indivisible part): Ibn al-Nadīm, Fihrist, ed. G. Flügel (Leipzig, 1871-2), p. 259.19-20. On the question of whether a visual ray or light ray is in fact a body, as opposed to being continuous like a body, see below.

${ }^{30}$ Properly speaking, the "rays" represented by the lines in the geometrical constructions are just formalizations of a continuous visual cone. Thus there is no concern that al-Kindī might be committed to an actually infinite number of visual rays coming from the eye, or that an actually infinite number of light-rays are emitted by a source of illumination. (He rejects this explicitly in another 
Now on these points al-Kindī is anticipated by Ptolemy, who writes:

Ptolemy, Optics §50, 37.4-8: it is not because it falls within the gap between visual rays that an extremely small visible object is not seen. On the contrary, it must be understood that, as far as visual sensation is concerned, the nature of visual radiation is perforce continuous rather than discrete (continua est necessario et non disgregata).

Ptolemy goes on to argue that if the visual cone were not continuous, then there would be gaps between the rays. But if there were gaps then we would not see even a very large magnitude whole at great distances. In fact, we would not see it at all, because the points (puncti) at which these separated visual rays would contact the object "have no size and do not subtend any angle." This last argument reappears in al-Kindī:

De Aspectibus Prop. 11, 11. 22-41: Since the line [...] is a magnitude having one dimension, length without width, whose extremes are two points at which it ends, which have no parts, and since it was already supposed in his [Euclid's] treatise on perspectives that something is grasped by vision only when a ray proceeding from vision falls upon it, then if what proceeds from vision is an infinite line [.. .] the end of such lines is a point grasping a point. But a point cannot be sensed, since it has no length, width or depth. What lacks length, width and depth is not sensed by vision. Therefore such a line senses what cannot be sensed. And this is another horrid absurdity. If such a line grasps points by means of its extremes, which are points, and only grasps that upon which it falls, then [the points] must have length and width. But he, and all mathematicians, say that points are without length and width. And this is again absurd.

Notice that the argument presented by al-Kindī is more general: not only will there be a problem about seeing small and distant objects, but in fact nothing would be seen at all, if the visual ray were not three-dimensional. ${ }^{31}$

These parallels show that a Ptolemaic inheritance - quite possibly indirect, via Theon of Alexandria - explains some of

optical work, the Rectification of Euclid's Errors, also edited and translated in Rashed, Euvres philosophiques, pp. 162-335, with this passage at 171.17-173.2.) Rather the cone is potentially infinitely divisible into rays, but no matter how small a visual ray we consider, it will be divisible into smaller rays that are still three-dimensional.

31 As Rashed, Euvres philosophiques, pp. 49-50, has pointed out, in this same proposition al-Kindi also takes an argument against gaps in the visual cone from the version of Euclid's Optics ascribed to Theon of Alexandria: he even uses the same example of seeing letters written on a page. The Rectification of Euclid's Errors also includes the argument about visual rays ending in points, put in very similar language: see p. 165.4-16. 
al-Kindī's divergences from Euclid. But as far as I can see there is nothing in Ptolemy to explain the most dramatic change al-Kindī makes to Euclid's theory: (C) his view that the propagation of light occurs in all directions and over the path of the light ray all at once. This is the most important of the three changes to Euclid mentioned above, since it underlies the punctiform analysis of visual rays and light rays. A possible source is the next work to be considered, John Philoponus' Commentary on the De Anima.

\section{I.2. John Philoponus, in DA}

Philoponus' stance towards Aristotle's theory of vision is not unlike al-Kindī's stance towards Euclid's: he generally defends the Aristotelian account, but introduces certain original ideas, especially having to do with the propagation of light. In his $D e$ Anima commentary, Philoponus argues (In DA 327.6-25) that light cannot be a body, because as a simple body it would move either in a circle (like the heavens) or a straight line in one direction (like fire, which goes up away from the center of the earth). For "the simple motions are two, either straight or circular" (In DA 327.7-8). Light cannot be a body, because it is propagated in straight lines (In DA 327.14: ep' eutheias) but in all directions, not in only one direction. ${ }^{32}$ This is a crucial admission by Philoponus, because as Richard Sorabji has pointed out, it represents a significant change in Aristotle's theory of vision. ${ }^{33}$ Aristotle holds that light is a first actuality produced in a medium by a luminous body (see further below, Part II). It becomes present in the entire medium without its

\footnotetext{
${ }^{32}$ His evidence that light moves in straight lines, namely an optical experiment where light shines through a slit and illuminates something on the far side of the slit along a straight path, also appears as a demonstration in De Aspectibus 6. Another source for the demonstration would have been Theon's recension of the Optics: see Rashed, Euvres philosophiques, pp. 47-8. The experiment was apparently a commonplace in the ancient tradition: Philoponus attributes it to "the practitioners of optics (hoi ta optika metiontes)" (In DA 327.15-16).

${ }^{33}$ R. Sorabji, "John Philoponus," in R. Sorabji (ed.), Philoponus and the Rejection of Aristotelian Science (London, 1987), pp. 26-30. See also R. Sambursky, "Philoponus' interpretation of Aristotle's theory of light," Osiris, 13 (1958): 11426, and J. de Groot, "Philoponus on De Anima II.5, Physics III.3, and the propagation of light," Phronesis, 28 (1983): 177-96. See further her book on the topic, de Groot, Aristotle and Philoponus on Light. For the views of Philoponus and other commentators on vision see now R. Sorabji, The Philosophy of the Commentators: 200-600 AD, 3 vols. (London, 2004), vol. 1, §1(f)-(g).
} 
presence in one part of the medium being in any sense prior to its presence in another part of the medium. Philoponus agrees that light is propagated through the medium instantaneously (it does not "travel"), but adds the new idea that light has direction. Thus it affects a part of the medium closer to the source of light, this part instantaneously affects the next part, and so on. ${ }^{34}$

Now, in Propositions 13-14 of De Aspectibus, al-Kindī demonstrates his punctiform analysis of the propagation of light. This theory entails that light is propagated in all directions in straight lines, which makes it possible to explain such phenomena as Philoponus' "stained glass" effect, whereby light shining through red glass will make a red mark on something along a straight line from the light source through the glass. ${ }^{35}$ In Proposition 15 we find al-Kindī's most extensive discussion of the process by which light is propagated. This proposition is worth quoting at length:

I say it is possible only that either (a) the affecting of air by vision and of all that is affected by vision happens either immediately (subito) from beginning to end, without one part preceeding another to the end of the visual path, or (b) the affection is part after part.

If it is affected part after part, then either (b1) the part contiguous with the visual organ is affected first, after which the part that follows it is affected by it, and so on until the final thing affected by vision, or (b2) the part contiguous with the visual organ is affected first, but then the part that follows it is affected by vision, and then the part that follows the second part is affected by vision, and so on until the final thing affected by vision, with the parts not being affected by one another.

But if (b1) the parts are affected by each other, it must be that all the parts that surround the first affected part are also affected, that is, all the parts contiguous with it. And all that are contiguous with the second affected part are affected by it, and so on until the final affected thing. It follows from this that the air in front of the visual organ and also behind it, or [behind] another affected part, is affected by vision. For all parts of the universe are continuous with one another, and not discrete. So it would follow that whoever wanted to behold something in a given part [of his surroundings] would see all the things [in all the directions] affected by vision, i.e. what is in front of him, what is behind him, and what is in all parts [of his surroundings]. But we find that the reverse is the case. For with our eyes we sense only that from which it is possible

${ }^{34}$ In DA 330.5-19. At 329.38-330.5 he compares this process to the propagation of heat through air, though presumably the analogy breaks down insofar as heat is propagated in time, whereas light is not.

${ }^{35}$ In DA 335.12-26. Cf. al-Kindi, On the Blue Color of the Sky, $\mathrm{AR}^{2} 108.4-5$. 
to draw a straight line to the part of the eye that sees. But it is impossible to draw a straight line from what is behind us to the seeing part of our eyes. Thus what is contiguous with [a part of the air] affected by vision is not affected [by that part].

Now, if (b2) the part contiguous with vision is affected first, then the second after that, then the third, and so on until the final affected thing, but all are affected by vision, not by the parts affecting one another, then this would happen in time, some being affected after others. It would follow that, when we want to see something that is one cubit away from us, we would not behold it until we attended to it for some period of time ... [But this is not the case. ${ }^{36}$ ] For, if we wish to see something that is as far away as we can see, so that its distance from us is that of the sphere of the fixed stars, there will still not appear to us any time between deciding to see the fixed stars [and grasping them], since as soon as we decide to see we behold what we want to, as long as it falls under vision, that is, at its center, and there is a luminous medium, with no obstacle between us and it.

Therefore visibles are not beheld in a process that requires time (cum tempore). Thus what is affected by vision is affected immediately, that is, from beginning to end, and not in time. And this is what we wished to demonstrate.

Now, this passage concerns not light, but the visual ray. However, as is suggested by other passages we have already seen, al-Kindi seems to assume that luminous and visual rays work the same way, so much so that some commentators have concluded that they are identical in nature. ${ }^{37}$ Al-Kindî's theory of how such rays are propagated is very close to Philoponus'

${ }^{36}$ I have omitted a demonstration designed to show that if the visual ray travelled in time, the distance of an object from the eye would be proportional with the time required to see it.

${ }^{37}$ Lindberg, “Alkindi's critique," p. 479: “it is impossible to make sense of Alkindi's argument unless we assume that implicit to it is belief in the identity of luminous and visual radiation." Travaglia, Magic, Causality and Intentionality, p. 53 is more circumspect. She remarks that the identical mechanics of the two sorts of ray need not imply complete identity. As she points out in her chapter on De Aspectibus, both light and vision are understood by al-Kindī as types of rays, $s h u^{\prime} \bar{a}^{\prime}$. The notion of the ray is a fundamental one in al-Kindī's thought, as we can see from his work De Radiis, also preserved only in a Latin translation. (For De Radiis see M.-T. d'Alverny and F. Hudry, "Al-Kindī, De Radiis," Archives d'histoire doctrinale et littéraire du Moyen Âge, 41 [1974]: 215-59.) Al-Kindī believes that there are many different sorts of rays that exercise different sorts of causality. In De Radiis he uses them to explain a variety of magical and astrological phenomena, for example. But this does not rule out that all rays are propagated according to the same laws. If this is so, then De Aspectibus 15 represents his fullest discussion of those laws. It should be noted, however, that there is evidence for the stronger thesis that luminous and visual rays are identical: in his Rectification of Euclid's Errors, al-Kindī calls the visual ray a "luminous power (quwwa nüriyya)" and a "radiant light (diy $\bar{a}$ ' $\operatorname{shu}^{\prime} \bar{a}(\bar{\imath})$ " (Rashed, Euvres philosophiques, p. 163.12,16). 
theory of how the energeia of light is propagated. First of all, al-Kindī's rays have direction: they are propagated along straight lines. Second of all, as he shows in his refutation of (b2), they do not travel in time. His argument here is again close to one of Philoponus', invoking our ability immediately to see something as far as the way as the heavens (In DA 325.6-15). But al-Kindī rejects one important aspect of Philoponus' theory, namely that light could be propagated from one part of the medium to another. In his criticism of option (b1), he argues that if a part of the medium possessed the power to transmit the visual ray, it would transmit the ray in all directions just as the surface of the eye does. But then the effect of the ray would spread beyond the cone projected from the pupil, so that we would even see behind ourselves. ${ }^{38}$

To this extent al-Kindī adheres more closely than Philoponus had to the original Aristotelian view that light, or here a visual ray, can fill a medium immediately without being in one part of the medium before another. (Here "before" should be taken in the sense of both temporal and causal priority: for al-Kindi there is no sense in which one part of the medium is affected prior to another.) On the other hand, though he rejects Philoponus' claim that the medium is affected part by part, al-Kindi retains the Ptolemaic and Euclidean notion that the propagation has direction along a straight line. Presumably, since there is no priority or posteriority among the affected parts of the medium, the "direction" is fixed only by the source of the ray. It begins at the eye, in the case of the visual ray, or the luminous object, in the case of a ray of light. The ray proceeds from this source and affects the whole medium at once, as Aristotle said. But it does so along a rectilinear path. This is why the ray is susceptible to geometrical formalization. The upshot is that, in defending an extramission theory of vision, al-Kindī may be borrowing ideas from Philoponus, who defends Aristotle's intromission theory against the extramission theory found in authors like Euclid and Ptolemy. Yet al-Kindī remains in one sense more Aristotelian than

${ }^{38}$ An interesting objection, since Philoponus is also worried about why, on the Aristotelian view, we do not see behind ourselves (In DA 330.32-331.1). As already mentioned, Philoponus like al-Kindī insists upon the directionality of light. This explains why an illuminated part of air does not just transmit light to all the other parts of air contiguous to it, but only to that part of the air that lies in the appropriate direction. 
Philoponus did on the question of how light is propagated: not part-by-part, but all at once.

The points of agreement and disagreement between Philoponus and al-Kindī are interesting in their own right; but is it at all plausible to posit a historical connection? The measure of Philoponus' influence on early Arabic visual theories can be taken by turning to a little-studied treatise called On Light, ascribed to the aforementioned Hunayn ibn Ishāa. ${ }^{39}$ In this short text the author sets out to prove, among other things, that light is not a body. His argument depends for the most part on Philoponus' proofs of the same point in the De Anima commentary. To sum up these parallels briefly:

On Light 1: Since light does not move in time it is not a body; this parallels Philoponus (In DA 327.1-4), especially the reference to the fact that the sun illuminates the entire horizon when it rises. ${ }^{40}$

On Light 2: Light moves in a straight line in any direction, rather than naturally up, down, or in a circle (In DA $327.7 \mathrm{ff}$ ).

On Light 3: If light were a body in air, it would be a body interpenetrating a body. Again, the parallel with Philoponus is stronger than that with Aristotle, with its claim that if bodies could interpenetrate the cosmos could fit into a mote ( $h a b \bar{a}$ ' $a$, 1109.10) (In DA 328.15). ${ }^{41}$

${ }^{39}$ Fì anna al-daw' laysa bi-jism (That Light is Not a Body). The Arabic text was edited by P. Cheikho, in al-Machriq: Revue catholique orientale bimensuelle, 2 (1899): 1105-15. For a German translation, see C. Prüfer and M. Meyerhof, "Die aristotelische Lehre vom Licht bei Ḥunain b. Ishāq," Der Islam, 2 (1911): 117-28. I will give page and line numbers to Cheikho's text when quoting directly, but otherwise give the section numbers, which are identical in the Arabic text and German translation.

${ }^{40}$ The parallel is much closer than that adduced by Prüfer and Meyerhof, who refer us to Aristotle, $D A 418 \mathrm{~b} 21 \mathrm{ff}$. Compare also Themistius, In De Anima, edited by R. Heinze, CAG 5.3 (Berlin, 1900), p. 60.25-27. English translation: Themistius, On Aristotle on the Soul, translated by R. B. Todd (London, 1996).

${ }^{41}$ The absurd consequence of fitting the heavens into a mote, or a grain of millet, is in fact a commonplace of later Greek philosophy in discussions of the interpenetration of bodies. But its appearance here in On Light certainly comes from Philoponus, given the identical context. It appears elsewhere early in the Arabic milieu: see H. Daiber, Das theologisch-philosophische System des Mu'ammar Ibn 'Abbād as-Sulamī, Beiruter Texte und Studien 19 (Beirut, 1975), pp. 124-5, on the view that if God can do the impossible He could fit the entire world into an egg. The Mu'tazilite al-Nazzāam argued against the interpenetration view of Dirār b. "Amr that a mountain could be made to fit into a grain of mustard: J. van Ess, "Dirār b. 'Amr und die 'Caymiyya': Biographie einer vergessener Schule,” Der Islam, 43 (1967): 241-79, and 44 (1968): 1-70, at p. 261. 
On Light 4: Light would make illuminated air more dense if it were a body (In DA 328.21-22).

On Light 5 and 11: As the opposite of darkness, which is not a body, light cannot be a body (paralleling In DA 341.23-27).

The rest of the treatise is also strongly influenced by the Aristotelian tradition, and some of it seems to have derived from texts other than Philoponus. ${ }^{42}$

But it would be hasty to conclude that the author of $\mathrm{On}$ Light, whether or not he was Hunayn, read a full Arabic (or Greek, or Syriac) version of the De Anima commentary. We know that Philoponus' commentary was an important influence on an Arabic paraphrase of the De Anima produced, it would seem, at the time of al-Kindī's circle. This paraphrase, which I will call $\operatorname{ArDA}$, has appeared in an edition, translation and commentary by Rüdiger Arnzen. ${ }^{43}$ Philoponus' influence on the paraphrase can be detected at various points, and a section of the work where his influence is particularly strong is the section on vision. ${ }^{44}$ As Arnzen has noticed, all of the parallels between Hunayn's On Light and Philoponus seem to have been via the medium of $\operatorname{ArDA}$ : frequently there is identical or nearly identical phrasing in the two Arabic texts. ${ }^{45}$ Most persuasively, in one case we find the same mistranslation in both Hunayn and the paraphrase: they both say that light would make air "become denser and darker" 46 by its presence, rather than "denser and thicker (puknoteron kai pachuteron)" as in Philoponus.

Al-Kindī would certainly have had access to Philoponus' commentary through the medium of $\operatorname{ArDA}$. And while not all of the passages in which Philoponus discusses the propagation of

${ }^{42}$ For example, the argument in On Light 6 that if light were fiery it would be extinguished by water appears already in Alexander of Aphrodisias, In Librum De Sensu Commentarium, edited by P. Wendland, CAG 3,1 (Berlin, 1901), p. 31.2-3. English translation: Alexander of Aphrodisias, On Aristotle on Sense Perception, translated by A. Towey (London, 2000).

${ }^{43}$ R. Arnzen, Aristoteles' De Anima, eine verlorene spätantike Paraphrase in arabischer und persischer Überlieferung (Leiden, 1998).

${ }_{44}$ Arnzen, Aristoteles' De Anima, pp. 257-65, with accompanying notes.

45 The passages in $A r D A$ corresponding to these parallels are: (paralleling $\mathrm{On}$ Light 1) 259.6-9; (paralleling On Light 2) 259.9-14; (paralleling On Light 3) 259.15-261.5; (paralleling On Light 4) 261.5-10; (paralleling On Light 5 and 11) 263.12-265.10. Arnzen notes the connection between On Light and ArDA on p. 400 of his Aristoteles' De Anima.

${ }^{46}$ They use the same root: Hunayn has adhlamat, 1109.14, while ArDA has șārat muḍhlim, 261.8. 
light are included in $A r D A$, in one passage (the same one paralleled by Hunayn, On Light 2) we find the ideas that are deployed in De Aspectibus 15:

ArDA 259.9-260.5 [cf. Philoponus in DA 327.6ff., 328.12ff.]:

He said that every body is either simple or composed. And body, whether simple or composed, moves either with rectilinear motion, like fire and air and the other primary bodies, or it moves with circular motion, like the heavens. And we see that light does not move with either a rectilinear or a circular motion. ${ }^{47}$ For it moves up, down, right, left, to the front, and to the back, without time (bi-la zamān). Thus light is not a body. And he said that if light were a body it would, when it goes (salaka) through the air, enter into it either all at once (bi-duf'a $w \bar{a} h i d a)$ or part after part (juz'ba'da juz'). And if it entered the air all at once, it would be necessary that one body enters into another, but this is absurd. But if it goes into it part after part, it would be necessary that light would not illuminate all the air at once without time, but rather little by little. And this is absurd. ${ }^{48}$ Therefore light is not a body.

We do not have the luxury of the original Arabic of $D e$ Aspectibus and therefore no opportunity for a direct comparison of the two texts. But I think it is clear that this passage of $\operatorname{ArDA}$ would explain the argument al-Kindi presents in Prop. 15. In view of this it seems that Philoponus did influence al-Kindī's theory of light, but indirectly. We do not need to suppose that al-Kindī had access to a separate translation of Philoponus' commentary, ${ }^{49}$ nor that he read

${ }^{47}$ As Arnzen, Aristotles' De Anima, p. 400, points out, what Philoponus is ruling out here is a simple rectilinear motion in a single direction, like that of fire: light does move in straight lines, but in all directions, and no body does this. He goes on to approve of the view that light moves in straight lines, as proven in optics, at In DA 327.15-16.

${ }^{48}$ The text is missing part of Philoponus' argument against this second option: see Arnzen's note ad loc.

${ }^{49}$ The question of whether his commentary was available to al-Kindī, or indeed ever in the Arabic tradition, is a disputed one. Arabic bibliographers (Ibn al-Nadīm etc.) do not mention the commentary; for a summary of their reports on the De Anima and its commentaries see F. E. Peters, Aristoteles Arabus (Leiden, 1968), pp. 40-5. For the status quaestionis on a possible Arabic version of Philoponus in DA see D. Gutas, “Avicenna's marginal glosses on De Anima and the Greek commentatorial tradition," in P. Adamson, H. Baltussen, and M. W. F. Stone (eds.), Philosophy, Science and Exegesis in Greek, Arabic and Latin Commentaries, 2 vols. (London, 2004), vol. 2, pp. 75-85, at p. 81. Gutas believes that Avicenna may have known the commentary, and reminds us that J. Jolivet, in his L'intellect selon Kind $\bar{\imath}$ (Leiden, 1971), sees influence from Philoponus' commentary on al-Kindī's theory of intellect. It is worth noting that ArDA itself, according to Arnzen, draws not on Philoponus' commentary itself but on an Alexandrian work that incorporated material from Philoponus: see Aristoteles' De Anima, pp. 80-108. 
Philoponus' views on light in any version more extensive than the one in $\operatorname{ArDA} .50$

That the specific passage in $A r D A$ lies behind De Aspectibus is suggested by a difference between $\operatorname{ArD} A$ and Philoponus, on precisely the point where al-Kindī disagrees with Philoponus: the question of whether light affects air "all at once" or "part by part." The passage just cited from ArDA assumes, as does al-Kindī's Prop. 15, that light will take time to move through the air if it affects the air part by part. But Philoponus does not, of course, assume this. Indeed, as we have seen, his position is precisely that the air is affected part by part, but that all the affected air is affected simultaneously. This is how he proves that light is not a body, but an immaterial actuality (In $D A$ 330.14-15). Philoponus thus would never have refuted the idea that light is propagated part-by-part by assuming that this would require time. So his argument, in the passage that parallels ArDA's proof that light is not a body, proceeds differently. The first horn of the dilemma is the same, that if light is a body and affects the air as a whole ( $d i^{\prime}$ holou), then we will have one body in another body, which is impossible (In DA 327.26-27). But the second horn of Philoponus' dilemma is different: in Philoponus' version, the other option is that light is only in a part of the air, but then the air will not be wholly illuminated. Al-Kindî's dilemmatic argument thus reproduces the version of the argument we find in $\operatorname{ArDA}$, not in Philoponus. And it would seem that al-Kindī was unaware of

${ }^{50}$ Or is there anything in De Aspectibus that shows Philoponus' influence and could not be explained by what we find in $\operatorname{ArDA}$ ? I have been unable to find anything convincing on this score: perhaps the most striking is a text in which Philoponus complains that a Euclidean theory of vision would face the problem that visual rays contact their objects only at points. (In DA 326.9-15: "In general, if vision occurs by something being emitted from the eyes, then necessarily the things emitted will be either bodies or, as the mathematicians seem to say, lines. But if the visual rays (opseis) go out as lines, it is clear that they will grasp the visible objects at points (kata sêmeia). But they say that vision occurs by contact of the rays with the visible objects. Then they will contact them at points; thus they lay hold of the visible objects at points. But then they lay hold of things that have no extension, which is absurd.") This, as we saw above, point (a), is found in al-Kindī as well as Ptolemy. But here al-Kindi's source would seem to have been Theon of Alexandria; see above, n. 31. Philoponus also makes remarks relevant to point (b), arguing, like al-Kindī and Ptolemy, that if there were gaps between the rays then vision would be spotty: see in DA 126.23-7. The point is made by al-Kindi most clearly in section 3 of his Rectification of Euclid's Errors. But again al-Kindī seems here to be dependent on the introduction to Euclid's Optics ascribed to Theon: see Rashed, Euvres philosophiques, pp. 49-50. 
Philoponus' view that light affects the medium all at once but also part by part.

Indeed, most likely he was unaware that Philoponus was the author of the ideas conveyed in $\operatorname{ArDA}$, since this is not mentioned in the paraphrase. Al-Kindi may even have supposed that the doctrine that light goes in all directions is orthodox Aristotelianism. We should not overlook, though, how much al-Kindī still had to do to arrive at his punctiform analysis of light. It was, as far as we can tell, original with him to apply Philoponus' claim that light goes in all directions to the visual ray, and to combine it with the distinctively geometrical understanding of vision and light found in Euclid and Ptolemy. It was this move that allowed al-Kindi to claim that we can formalize light or the visual power as a set of lines proceeding from points on the surface of a luminous body or the eye. Thus the main contribution of De Aspectibus to visual theory was, to this extent, al-Kindī's own. ${ }^{51}$

\section{AL-KINDĪ ON THE CAUSE OF COLOR}

As mentioned above, al-Kindī's corpus includes not only several works on geometrical optics, but also two treatises on the cause of color. I will argue that the two treatises represent an original and unique response to the Aristotelian theory of vision, as mediated through Alexander of Aphrodisias. At the same time, I will further suggest, even in these non-optical works al-Kindi is trying to leave room for the theory of vision he holds in De Aspectibus. In fact, the aspect of his theory that departs most strikingly from the Aristotelian tradition may be explained with reference to Ptolemy's Optics.

The first of the two works in question, On the Bearer of Color $\left(\mathrm{AR}^{2} 64-8\right)$, is a brief demonstration of the general claim that color is caused by the presence of earth in what is visible. Al-Kindī proceeds by pointing out that earth is the only

\footnotetext{
${ }^{51}$ A further question raised by al-Kindì's dependence on the $\operatorname{ArDA}$ passage is whether al-Kindī followed Philoponus and $\operatorname{ArDA}$ in holding that light is not a body. Though he does not emphasize the point, as $\operatorname{ArDA}$ and $O n$ Light do, I suspect that he did accept the incorporeality of light. Nowhere, that I have found, does he say that light is a body, and he seems to be careful to use terms to describe light in De Aspectibus that would avoid suggesting light is a body: for example impressio (e.g. in Prop. 11, presumably translating athar) and virtus (e.g. in Props. 7, 22, presumably translating quwwa). On light as virtus see Travaglia, Magic, Causality and Intentionality, p. 62.
} 
element that blocks vision. That is, one cannot see through what is earthen or has earth in it. This is not so for the other three elements, which are transparent. Even fire, which might be thought to have color, only seems to be visible because of the earthy parts of what is being burnt. The second treatise, On the Cause of the Blue Color of the Sky ( $\left.\mathrm{AR}^{2} 103-8\right),{ }^{52}$ is devoted to the more specific question of why the sky is blue. The addressee of the epistle has posed the question to al-Kindī, perhaps as a puzzle raised by the doctrine of On the Bearer of Color. If we only see color because of earth, and there is no earth in the sky, then why does the sky look blue? The answer is consistent with On the Bearer of Color. After again stressing that fire is in fact transparent, contrary to what one might think, al-Kindī argues that the sky is colored because of non-transparent particles distributed through the air. When these particles are struck by light reflected from the earth and emitted from the stars, we see a color partway between pure light and pure dark, in this case the color blue.

The context of these two epistles, unlike that of De Aspectibus, is Aristotle's theory of vision. In both al-Kindī deals principally with the transparent, which is crucial in Aristotle's account of sight. He defines color as the proper object of sight $\left(\mathrm{AR}^{2}\right.$ 65.3-4), just as Aristotle does, and mentions the requirement that there be a medium of illuminated air between eye and visible object $\left(\mathrm{AR}^{2}\right.$ 65.8-9, 65.11; see below for further discussion of this passage). Aristotle is thus, as so often, the starting-point for al-Kindì's discussion. Yet the specific issue dealt with here is not one found in Aristotle, who never raises the question of which element causes, or literally "bears (hamala)" color. Although later commentators come closer to raising the issue, we will see that for very good reasons none of them suggest that the presence of earth is what gives rise to color.

The fundamental concept in Aristotle's color theory is the transparent (to diaphanes). The transparent is mentioned most prominently in De Anima II.7, where it is said to belong to bodies like air and water. Such a body is in itself only potentially transparent; this transparency is actualized by the presence of light. Actual transparency is the capacity of that

${ }^{52}$ A not entirely reliable English translation has been published in O. Spies, "Al-Kindī's treatise on the cause of the blue colour of the sky," Journal of the Bombay Branch of the Royal Asiatic Society, 13 (1937): 7-19. 
body to receive color. Thus, in order for us to see, what must happen is that a potentially transparent medium lies between us and the visible object, which is colored. When light is present in the medium, the medium becomes actually transparent, and so able to transmit the color of the object to our eye. Turning to De Sensu, however, we find a rather different use of the notion of transparency, according to which all bodies are to varying degrees transparent: "the transparent, in the measure that it is present in bodies (for it is present in all of them to a greater or lesser extent), makes them share in color" (459b8-10). Color in fact is the limit (eschaton) of the transparent that is in bodies.

There is an obvious problem that arises when we try to bring these two aspects of the transparent together into a single doctrine: in the medium, transparency is supposed to be the ability to receive color, rather than being responsible for color itself. Indeed, if the medium were colored by being transparent, it could not serve as medium at all, because to play that role it needs to be in itself only potentially colored. The commentary of Themistius brings this fact out nicely. In the Arabic version of Ishāa ibn Hunayn (the son of Hunayn ibn Ishāq), ${ }^{53}$ the commentary reads: "all these [transparent] things are not seen via ( $\min$ haythu) a color they have as proper to them. For none of the transparent things are colored, but rather the things that are furthest away from colors are the ones that are properly transparent. So they are seen when they are seen via the color of something else." It seems to follow from this that the transparent is what has no color, and this is in fact precisely what al-Kindi says $\left(\mathrm{AR}^{2} 65.13-15\right)$. How then can the transparent in bodies be responsible for their colors?

For the ancient commentators the answer depends on the analogy Aristotle draws several times between color and light. As we saw, light is a first actuality that makes a transparent medium actually transparent. Color is the second actuality of the same medium. (To compare this to Aristotle's famous example of the grammarian at De Anima II.5, light is like the ability to do grammar, whereas color is like actually doing

\footnotetext{
${ }^{53}$ Ishāq (d. ca. 299 / 911) belongs to the generation after al-Kindī, and outlived him by about forty years, so it is doubtful whether al-Kindī could have read this translation. The Arabic text can be found in M. C. Lyons, An Arabic Translation of Themistius' Commentary on Aristotle's De Anima (Oxford, 1973). The passage cited here is based on Themistius In DA 60.36-38.
} 
grammar. ${ }^{54}$ ) Now, Alexander understood the theory of color in De Sensu to preserve a strict identity between the color present in the medium and the color present in an object. If color in the medium is the actualization of the actually transparent, then color in the colored object must be the actualization of actual transparency in the object. ${ }^{55}$ Thus the red of an apple is merely the actualization of the apple's transparency. The only difference between the two cases is that the medium is an "indefinite (aoristos)" body, because it has no defined boundaries. The colored object is a "definite (diôrismenos)" body, and its boundaries are its colored surfaces. This is why color may also be defined as the surface of the visible body (as the Pythagoreans did, according to Aristotle, De Sensu 439a31-32). Because of its lack of a boundary the indefinite body has no color of its own, so it can take on the first actuality of light and the second actuality of color so as to serve as a medium, without itself looking colored (Alexander, In De Sensu 45.17-20).

Though it may sound strange to say that something like an apple is visible because it is transparent, this is merely because the apple is not fully transparent, the way air or water is. In fact, Alexander says, bodies have varying degrees of transparency, just as they vary in their degree of heat or moisture (In De Sensu 44.22-25). It is these varying degrees of transparency that give rise to color. White is due to the presence of a high degree of transparency in a definite body, and the spectrum of colors corresponds to a decreasing scale of transparency until we reach black. It is here that Alexander addresses al-Kindī's question about which element is responsible for color. He says that the varying degrees of transparency in a definite body are due to the proportion of elements in that body: air is the most transparent, water somewhat less so (In De Sensu 46.3-6). Earth, meanwhile, is "least transparent (elachista diaphanês)" (In De Sensu 46.6), and we know this because "it does not admit light in itself, and blocks

\footnotetext{
${ }^{54}$ For extensive discussion of the notions of actuality in Aristotle's theory of light, see de Groot, Aristotle and Philoponus on Light.

55 For Alexander's treatment of light and color see Alexander, In De Sensu 42.21-66.6. See also Alexander of Aphrodisias, Scripta Minora, edited by I. Bruns, Supplementum Aristotelicum II.1 (Berlin, 1887), pp. 5.1-7.19, which deals with the topic of color. English translation: Alexander of Aphrodisias, Quaestiones 1.1-2.15, translated by R. W. Sharples (London, 1992). The Arabic version of this Quaestio will be discussed below.
} 
whatever else it is mixed with and hinders it from being wholly illuminated" (In De Sensu 46.14-16).

At first glance it might seem that this doctrine is very like the one we find in al-Kindi. Earth, because it is so far from being transparent, gives rise to dark colors, if not color generally. But in fact al-Kindī's position is diametrically opposed to Alexander's. For Alexander, the more transparent something is, the more color it has, and the more visible it will be when its transparency is actualized. Thus white is the most visible color, since it is due to the highest degree of transparency possible in a colored definite object. For al-Kindi the situation is the reverse: the more transparent (mushiffān) something is, the less visible it will be. It would seem to follow from this that black is the most visible color, because al-Kindi thinks objects are colored only insofar as they obstruct vision. He says that earth "blocks and resists vision, i.e. it is not transparent" (65.7). It is thus not the transparent that produces color, but that which is "dense" or a "blockage" to our sight (al-inhișār, used in both treatises on color, e.g. at $\left.\mathrm{AR}^{2} 66.8,104.1-3\right)$. What separates Alexander and al-Kindī is that Alexander has a positive conception of the transparent. For him, as for Aristotle, the actually transparent requires the presence of the actuality that is light, and it has the positive characteristic of being able to transmit color. For al-Kindī, by contrast, the transparent is defined negatively: vision does not see it, but sees whatever is on the far side of it $\left(\mathrm{AR}^{2} 65.7-8\right)$. Transparency is then not an actuality or a capacity, but a privation: specifically, a privation of what is colored, which is what intercepts vision so that we can see it. This is why I have said that the two views are diametrically opposed: Alexander says that color is caused by the transparent, whereas al-Kindi says that color is caused by whatever lacks transparency, namely earth.

The contrast between Alexander and al-Kindi is all the more striking in light of the fact that al-Kindi may well have known Alexander's doctrine of color. It is not impossible that he read the commentary on De Sensu, which was translated into Arabic by Hunayn ibn Ishāa. ${ }^{56}$ But the doctrine was also preserved in a Quaestio by Alexander or his school, entitled Peri Chrômatos Tina, and translated into Arabic probably at the time of

${ }^{56}$ See Peters (1968), p. 46. 
al-Kindī's translation circle. ${ }^{57}$ The Arabic version of this work repeats many of the points made by Alexander's In De Sensu, in terminology close to al-Kindī's treatises. So for example, it asserts that not earth, but the medium, is the "bearer ( hâamil)" for color (25). It also says that white, which is the "true color (al-lawn al-haqq)," results from the presence of a high degree of transparency in a body (80-1). So it would seem al-Kindī could seek little support for his own view in this text. On the other hand, the short treatise could have been al-Kindî's source for the notion that earth is the element that is not transparent:

We say also that among the simple bodies fire falls under vision [the most]. It is very transparent in its nature. Therefore it is able to illuminate the air and give it the perfection $(t \bar{a} \mathrm{~mm})$ of color, like its own perfection $(\operatorname{tam} \bar{a} m)$. For earth has no transparency at all (88-91).

One might of course ask Alexander how we see earth at all, if it has no transparency. The answer would seem to be that such a body would be black, and that "black is not a color" (85), but rather the result of a lack of transparency (43-4). ${ }^{58} \mathrm{We}$ see earth the same way we see darkness: as a privation of light and color. ${ }^{59}$

If al-Kindī knew Alexander's interpretation of Aristotle, what inspired him to take such a contrary position? Again, it is natural to look for another source in the Greek tradition,

57 The Arabic version has been edited and translated into German in H. Gätje, "Die arabische Übersetzung der Schrift des Alexander von Aphrodisias über die Farbe," Nachrichten der Akademie der Wissenschaft in Göttingen, philologischhistorische Klasse, 10 (1967): 343-82. Citations are to line numbers of this Arabic text. One manuscript of the Arabic version claims that the translation was by Ishāa ibn Ḥunayn and by Abū 'Uthmān al-Dimashqī (fl. about A.D. 900), either of which would suggest that the text could well have been translated after al-Kindī's death. But an analysis by Gätje has shown that the translation probably dates from before the school of Hunayn ibn Ishāq, which would rule out both his son Ishāq and his disciple al-Dimashqī as translators, and put the text back into al-Kindī’s period (see Gätje, “Die arabische Übersetzung," p. 355).

${ }^{58}$ Cf. Alexander In De Sensu, 47.18-19.

${ }^{59}$ In claiming that earth is not at all transparent, the Arabic version departs from Alexander's Quaestio, which like In De Sensu claims that earth is "least (hêkista)" transparent (Scripta Minora 7.4). Priscian also argues that earth is minimally transparent: "but perhaps we are incorrect in taking the transparent to be in earth, if the transparent is receptive of light. Or, we are not incorrect: for it was said that [the transparent] is receptive not only of light but also of darkness. So earth too is colored, color being the limit of the transparent in defined bodies." Priscian of Lydia, Metaphrasis in Theophrastum, edited by Bywater, CAG suppl. I,2 (Berlin, 1886), 8.16-20. English translation: Priscian, On Theophrastus on Sense-Perception, translated by P. Huby (London, 1997). 
and again, a possible source presents itself in the shape of Ptolemy's Optics. At the outset of this work, before explaining the mechanism of the visual cone, Ptolemy makes the more basic point that we see an object when that object blocks the visual ray ( $\$ 2,12.5-6$ : prohibente penetrationem). He writes:

Ptolemy, Optics §4, 12.14-18: Now luminous compactness is what is intrinsically visible, for objects that are subject to vision must somehow be luminous, either in and of themselves or from elsewhere, since that is essential to [the functioning of] the visual sense; visible objects must also be compact (spisse) in substance in order to impede the visual flux, so that its power may enter into them rather than pass through without incident effect.

Ptolemy's account of what makes something visible corresponds exactly to we find in al-Kindī: if an object is dense enough to block the visual ray, and also to intercept light rays to as to become illuminated, then it will be seen when the visual ray falls upon it. ${ }^{60}$ Ptolemy even ties this notion of density or compactness to color: "objects that have no compactness (spissitudinem), but are exceedingly tenuous and have no color, are neither sensed nor perceived as bodies by the visual faculty" ( $\$ 6,13.10-12)$.

From a modern point of view the agreement between al-Kindi and Ptolemy might seem unremarkable, since for us the idea that visibility and density are linked is simply common sense. But against the background of the Aristotelian color theory this was anything but obvious. For an orthodox Aristotelian like Alexander, vision occurs thanks to the visible object's transmitting a form to us, and it is highly colored (i.e. highly transparent) objects that do this most of all. Only someone with an anti-Aristotelian, extramissionist theory of vision - like the one we find in De Aspectibus - could think that objects are visible because they block or intercept our vision. Without being more confident about the sources al-Kindī had available to him, it is impossible to say whether he had Ptolemy in mind when he wrote the color works. And in any case, Ptolemy does not address himself to the physical question of

${ }^{60}$ Here it is worth noting that the Ptolemaic ideas in De Aspectibus come ultimately from the earlier sections of Ptolemy's Optics, just as does the idea that the dense is the visible. A plausible hypothesis then is that al-Kindī's source included ideas from these opening sections of the Optics but not the theory of refraction. 
what accounts for this compactness in visible objects. AlKindî's identification of earth as the sole cause of visibility ${ }^{61}$ is original with him, though as we have seen it could have been suggested by his reading of Peripatetic discussions of how the elements relate to color, and in particular by Alexander's statement that earth is the least transparent of the elements. ${ }^{62}$

Whatever his sources, al-Kindi's account of color fits much better into the theory of vision defended in De Aspectibus than it would into an Aristotelian theory. This is not only because of the notion that the visible blocks vision, but also because of the nature of the transparent as it is presented in the color works. If color is seen when rays from our eye make contact with an illuminated and colored (i.e. dense) surface, then there is nothing for the transparent to do in the visual process. The transparent does not need to be an actualized disposition for transmitting color, it just needs not to get in the way of the visual ray. Hence I have called his conception of the transparent "negative," in place of the "positive" Aristotelian conception. A final point is that al-Kindi says, in On the Blue Color of the Sky, that light goes from the sun to illuminated places on the earth along straight lines, just as in the optical works ( $\left.\mathrm{AR}^{2} 104.4-6\right)$. These rays convey heat as well as light, and in describing this al-Kindi even uses the term "rays $\left(s h u^{\prime} \bar{a}^{\prime}\right)$," found also in his optical works (and presumably in the original Arabic of De Radiis), to describe the heating light that is reflected from the earth into the air $\left(\mathrm{AR}^{2}\right.$ 107.16).

All of this suggests that al-Kindi held something like the $D e$ Aspectibus theory of vision when he wrote the color treatises. He held, that is, an extramission view with a negative conception of the transparent and a linear understanding of light. But there is an obvious problem for this theory: why can we only see something when there is light? Al-Kindī gives two reasons. First of all, the visual ray will not let us see an object if that object is not illuminated. The same spot on the object's surface

${ }^{61}$ The only exception he allows $\left(\mathrm{AR}^{2} 107.12-15\right)$ is that the heavenly bodies are also "dense" and thus block vision, as can be seen from the fact that they can eclipse one another (e.g. we cannot see the fixed stars through the moon). And we know that, for al-Kindī, the heavenly bodies contain no earth but are made of a fifth element: see his On the Explanation that the Nature of the Celestial Sphere is Different from the Natures of the Four Elements ( $\left.\mathrm{AR}^{2} 40-46\right)$.

${ }^{62}$ Compare Philoponus, In DA 324.33-35: "Because light is present we see through air and water, but not through earth, since clearly it does not have in itself the nature of the transparent in potency." 
must be struck simultaneously both by a ray of light and a visual ray. Thus in On the Blue Color of the Sky, when al-Kindi says that air is "dark" ( $\left.\mathrm{AR}^{2} 107.11\right)$, he means that it cannot intercept light the way a dense body can, and so will never be illuminated so as to be visible in itself. ${ }^{63}$ In order for a visual ray to interact with a colored surface, a ray of light must strike the same surface at the same time (cf. Ptolemy, Optics $\$ 16$, 10-11). This is the first role light plays in al-Kindî's theory: it is a necessary condition for the interaction of visual ray and colored surface. As al-Kindī puts it in De Aspectibus, Prop. 12, "I say that we do not see any color to be grasped in a dark place, unless light enters into it. If, then, the light is strong, the color will be clearer, and if it is weaker, then the color will be more obscure."64 In Aristotelian terms, one might say that for al-Kindī a colored surface is only potentially visible, and that the light ray actualizes the color to make it actually visible. ${ }^{65}$

But there is a second function of light in al-Kindî's account, which is more problematic. In On the Bearer of Color al-Kindi says three times in close succession that we see objects through the transparent, but only when "there is an intermediary (tawassut) of illuminated air between vision and that whose color is seen" (65.5-12). He says the same in De Aspectibus in Prop. $8 .{ }^{66}$ Now, there does need to be illuminated air between

${ }^{63}$ Compare De Aspectibus 10: radius vero est impressio corporum luminosorum in corporibus obscuris. I think Travaglia's interpretation of this statement is correct: the "ray" itself is not the spot of light on an object, but the three-dimensional path of the light through the non-resistant air (see Travaglia, Magic, Causality and Intentionality, p. 61). The reference to transparent air as having "the nature of darkness" in On the Blue Color of the Sky further explains why De Aspectibus here has "in corporibus obscuris," which must refer to the medium and not the visible object. Interestingly, Ptolemy (Optics §19, 20.13) says it is "due to air's blackness (de negridine aeris)" that distant objects look dimmer. Strictly speaking this should be understood differently than al-Kindî's statement: for air actually to make things look darker, it would have to have a dark tint of its own, rather than just being incapable of intercepting light rays.

${ }^{64}$ Cf. Ptolemy, Optics \$19, 6-8, and Smith, Ptolemy's Theory, ad loc.

${ }^{65}$ As Gätje has shown in "Zur Farbenlehre in der muslimschen Philosophie," Der Islam, 43 (1967): 280-301, one of the controversial questions about color in Arabic philosophy was whether color exists in the dark actually or only potentially. Al-Kindi seems to anticipate the widespread view that color is actual only when illuminated.

66 "Vision only grasps its object by a power proceeding from itself, converting the air along straight lines, when the medium of light (lumen medium) is interposed between it and its object" (455.15-18). Compare this to his characterization of the Aristotelian theory of vision he rejects (Prop. 7), translated above in Part I. 
the light source and the visible object: light rays fill the air as they travel to the object and render the colors visible. But there is no obvious need for there to be illuminated air between the eye and the visible object. ${ }^{67}$ For al-Kindi has rejected the notion that the transparent medium plays a positive role in vision by conveying the color from the object to the organ of vision. ${ }^{68}$ Here it would seem that al-Kindī has erred out of misplaced fidelity to Aristotle, and, surprisingly, even carried this error across to anti-Aristotelian optical works like De Aspectibus.

This brings us back to the broader question of how al-Kindi handled the various sources that influenced his theory of vision. Though I have generally presented al-Kindī as being confronted with two utterly incompatible types of sources, from the Aristotelian tradition on one hand and the Euclidean and Ptolemaic tradition of geometrical optics on the other, in fact the situation is more complex. As mentioned above, in the Meteorology Aristotle himself does not hold to the theory of the De Anima, embracing instead an extramission theory like that later adopted by Euclid. Al-Kindī almost certainly knew the Meteorology. It was translated into Arabic by Yahyā ibn al-Bițrīq, and later paraphrased independently by Ḥunayn ibn Ishāâ. ${ }^{69}$ The influence of the Meteorology may have encouraged

67 Suppose you are looking across a dark field at night, towards a stone lit up by a spotlight (which is not also illuminating the air over the field). Obviously you will see the stone. If we drop the requirement for an illuminated medium, al-Kindi's theory can explain this: the dark air over the field allows the visual ray to pass through and make contact with the stone, and light rays are falling on the stone from a different direction and affecting its surface. But if we add the commitment to an illuminated medium, it becomes inexplicable.

68 As mentioned in n. 66, al-Kindī believes the visual ray "converts" the air along straight lines as it is propagated. In De Aspectibus 13 al-Kindī proves that the same is true of light: "the luminous body illuminates the body upon which light falls [by] transforming (convertendo) the air" between itself and the illuminated body. This suggests that there needs to be a medium of air between eye and visual object, and between light source and lit object, if the visual and light rays are to be transmitted. But this still does not explain why the medium between the eye and the object needs to be illuminated; rather it need only be transparent. By contrast, Ptolemy does not require that the medium between eye and object be illuminated, though as we have seen, in $\$ 19$ he suggests that objects surrounded by illuminated air are seen more clearly.

69 For the former version, see C. Petraitis, The Arabic Version of Aristotle's Meteorology (Beyrouth, 1967), reviewed by G. Endress in Oriens, 23-24 (1974): 497-509. For Ḥunayn's briefer summary paraphrase, see H. Daiber, Ein Kompendium der aristotelischen Meteorologie (Oxford, 1975). Petraitis gives two parallels that may show al-Kindī was familiar with the Meteorology in the version of al-Bițīq: Petraitis, The Arabic Version, p. 15 n. 1, 35 n. 2. 
al-Kindī in his project of combining the various Greek theories of vision, and it also seems to underlie some of the physical claims made in the works we have been examining. The best example is De Aspectibus Prop. 8, where al-Kindi records the supposed phenomenon of a man who sees his own reflection because his weak vision cannot penetrate the air, and is reflected back to him. This is taken from Meteorology 373a35$373 \mathrm{~b} 10.70$

There are further examples in On the Blue Color of the Sky. As we have seen, al-Kindî's view requires that small particles of earthy matter rise into the air where they can be illuminated by sunlight. Here al-Kindi makes use $\left(\mathrm{AR}^{2} 105.6-12\right)$ of a phenomenon frequently mentioned in the Meteorology: that heated particles rise in the air until they cool down. ${ }^{71}$ When Aristotle explains rainbows in the Meteorology he refers to these atmospheric particles, saying that the colors of the rainbow result from the meeting of our visual rays with the droplets in the sky. The explanation is reminiscent of al-Kindī's solution to the problem of the sky's color. ${ }^{72}$ Finally, al-Kindī's favorite example of the flame whose colors are not from fire, but from what is being burnt, may be related to Aristotle's statement that flames can appear red when they are mixed with smoke (Meteorology 374a5-8). ${ }^{73}$ All of this would have encouraged him to attempt a harmonization of Aristotle with Euclid, especially given the obvious empirical deficiencies of Aristotle's De Anima account of vision.

What we have in the works al-Kindi wrote on vision is in this respect a continuation of the process of interpretation we find among the late ancient commentators. Al-Kindī, like Alexander and Philoponus, tries not only to reconcile doctrines that are in tension with one another, but also to revise those

${ }^{70} \mathrm{Al}$-Kindī may be dependent here on al-Bițrīq's version. A good piece of evidence for this is the way the term "image (eidôla)" is translated: the Arabic of al-Bițīq has "shakhṣ," which literally means "individual" (Petraitis, The Arabic Version, p. 92.6). When we turn to De Aspectibus, we see that the word for the image is in Latin singularia. I hypothesize that this translates al-Kindî's own use of the word shakhs or (in plural) ashkhās here. But see Rashed, Euvres philosophiques, p. 454, n. 16 for a different explanation of the Latin here.

${ }^{71}$ See Meteorology 346b, 347a, 349b, 369a, etc.

72 The particulate is referred to as "vapor (bukhār)" both in the Arabic Meteorology of al-Bitrīq (Petraitis, The Arabic Version, p. 92.10) and al-Kindī (p. 105.8-9 and 105.13).

${ }_{73}$ Cf. Daiber, Ein Kompendium, p. 59.7-10. 
doctrines in accordance with the facts. In optics, his divergences from Euclid in both De Aspectibus and the Rectification of Euclid's Errors are ample proof that al-Kindī was willing to criticize and modify his Greek sources. The works on color show that he was no more slavish when it came to reading Aristotle. His departures, though, are often inspired by ideas from other Greek works, such as Philoponus' De Anima commentary and the Meteorology of Aristotle himself. The problems confronted in De Aspectibus and the works on color come from Greek texts recently translated into Arabic, as do the materials al-Kindī deploys to solve those problems. The solutions themselves, though, are al-Kindī's own. ${ }^{74}$

${ }^{74}$ I am very grateful to Charles Burnett, Elaheh Kheirandish, Stephen Menn, Peter Pormann and two anonymous referees from this journal for their comments on earlier drafts of this paper. 